\title{
Groundwater quality and human health risk assessment related to groundwater consumption in An Giang province, Viet Nam
}

\author{
Đánh giá diễn biến chất lượng nước ngầm và rủi ro sức khỏe liên quan đến sử dụng nước ở \\ tỉnh An Giang, Việt Nam
}

\author{
PHAN Kim Anh*; NGUYEN Thanh Giao
}

Department of Environmental Management, College of Environment and Natural Resources, Can Tho University. 3/2 Street, Ninh Kieu District, Can Tho City, Viet Nam

\begin{abstract}
Groundwater is one of the main sources for water supply for domestic use, irrigation, aquaculture and industry in Mekong Delta. With rapidly increasing in human population, groundwater becomes more important for social and economic activities. This study evaluated the quality of groundwater using data from the eight monitoring wells over the period of 2009 - 2016. Human health risk was assessed for the population consuming groundwater contaminated with arsenic. The findings indicated that groundwater wells in An Giang province were contaminated with microorganisms. The total dissolved solids (TDS) and hardness in Phu Tan (PT) and Cho Moi (CM) wells were significant higher than the national technical regulations on groundwater quality (QCVN 09-MT:2015/BTNMT). In addition, groundwater wells in some small islands of An Giang were seriously contaminated with organic matters and arsenic. The mean arsenic concentration was up to $0.55 \pm 1.21 \mathrm{mg} / \mathrm{L}$. Estimation of carcinogenic risk for human population showed that the cancer risks ranged from medium $\left(8.66 \times 10^{-4}\right)$ to high $\left(8.26 \times 10^{-2}\right)$ for both children and adults. Alternative water supply sources should be offered for the population at risk. Besides, regular health check is essential for local people in the arsenic contaminated groundwater.
\end{abstract}

Nước ngầm là một trong những nguồn cung cấp nước chính cho sinh hoạt, tưới tiêu, nuôi trồng thủy sản và công nghiệp ở Đồng bằng sông Cửu Long. Cùng với sự gia tăng dân số, nước ngầm ngày càng đóng vai trò quan trọng hơn trong các hoạt động phát triển kinh tế - xã hội. Nghiên cứu đã tiến hành đánh giá diễn biến chất lượng nước ngầm thông qua số liệu của tám giếng quan trắc trong giai đoạn từ năm 2009 - 2016. Kết hợp với đánh giá rủi ro sức khỏe của người dân khi sử dụng nước ngầm chứa arsenic. Kết quả nghiên cứu cho thấy các giếng nước ngầm ở tỉnh An Giang đã bị nhiễm vi sinh. Tổng chất rắn hòa tan (TDS) và độ cứng ở trạm Phú Tân và Chợ Mới phân tích được cao hơn quy chuẩn cho phép (QCVN 09-MT:2015/BTNMT). Các giếng nước ngầm ở một số khu vực cù lao của tỉnh An Giang đã bị ô nhiễm hữu cơ và arsenic nghiêm trọng. Nồng độ arsenic trong nước ngầm có thể dao động lên đến $0.55 \pm 1.21 \mathrm{mg} / \mathrm{L}$. Rủi ro ung thư ở hai đối tượng người lớn và trẻ em khi sử dụng nước ngầm nhiễm arsenic dao động từ trung bình (8 người trong 1.000 người) tới cao (8 người trong 100 người). Cung cấp nguồn nước thay thế là giải pháp khả thi để giảm rủi ro sức khỏe cho con người trong trường hợp này. Ngoài ra, người dân địa phương cần được khám sức khỏe thường xuyên để kịp thời phát hiện và sớm điều trị bệnh.

Keywords: carcinogenic risk, groundwater, arsenic, health risk assessment

\section{Introduction}

In the Mekong Delta, the main water resources include rainwater, surface water, and groundwater. The groundwater in this region has been exploited for domestic use since the beginning of the $20^{\text {th }}$ century (Hoang et al., 2010). Because of increasing development, the long dry season in the southwest of Vietnam, and pollution of surface water from salinity, acidity, domestic wastes and suspended sediment, groundwater use is growing. These serve about 4.5 million people (accounting for $32.1 \%$ ) out of the Delta's total population of 14 million (Ghassemi and Brennan, 2000).
In addition, according to Vietnam's Department of Water Resources Management (2009), there are many urban areas which use almost 100\% groundwater such as Ca Mau, Bac Lieu, Soc Trang and Tra Vinh province. An Giang province of Vietnam has large reserves of groundwater that can be abstracted for serving for daily life, irrigation, aquaculture and industry. According to the Geological and Hydrological Federation, groundwater along Hau River and in the Northwest of the province can be exploited at the depth of $80-100 \mathrm{~m}$ and $250-300 \mathrm{~m}$ with the exploitable amounts reaching $30,000 \mathrm{~m}^{3} /$ day and potential reserve of 85,000 $\mathrm{m}^{3} /$ day (An Giang People's Committee, 2015). In recent 
years, the major industrial activities, for example, processing of agricultural and fishery products and other sectors, have also remarkably increased. In 2012, the agricultural production value of the province was over USD 353.2 million and tended to increase over years (up 2.3\% compared to 2011). The average Gross Domestic Product (GDP) growth rate was 8.63\% (2011 - 2015) (An Giang People's Committee, 2015). The statistical numbers in the growth of GDP indicated that social and economic activities have increased continuously, and this could lead to a large amount of wastes from agricultural, industrial activities and other sectors generated. The generated wastes have been dumped or improperly treated resulting in contaminating both surface and groundwater sources.

Arsenic is naturally occurring substance. Arsenic pollution in groundwater has become a great concern of An Giang province. According to An Giang People's Committee (2015), 1,319 groundwater wells (accounting for 14.4\% of the total numbers of groundwater wells) in An Giang have been discovered contaminated with arsenic at the concentration of greater than $50 \mu \mathrm{g} / \mathrm{L}$ while 756 wells with arsenic at concentration of greater than $10 \mu \mathrm{g} / \mathrm{L}$. Long-term exposure to arsenic has been associated with cancer in skin, lungs, urinary bladder, kidney and liver, as well as various non-cancer effects. Recent studies also indicate that arsenic exposure could affect the reproduction and child development (Appelo, 2006).

This study aimed to assess the quality of groundwater at eight monitoring wells from 2009 to 2016 to identify trends in groundwater quality and to assess health risks for the population using arsenic-contaminated groundwater. The obtained results could provide additional data on the progress of groundwater quality in An Giang province and assess potential impacts for humans such as cancer risk associated with groundwater use.

\section{Materials and methods}

\subsection{Sources of groundwater quality data}

Groundwater quality data from eight monitoring wells in the period 2009 - 2016 in An Giang province including temperature, $\mathrm{pH}$, total dissolved solids (TDS), hardness $\left(\mathrm{Ca}^{2+}\right.$ and $\left.\mathrm{Mg}^{2+}\right)$, nitrate $\left(\mathrm{NO}_{3}{ }^{-}-\mathrm{N}\right)$, ammonium $\left(\mathrm{NH}_{4}{ }^{+}-\mathrm{N}\right)$, coliforms, total iron (Fe) and arsenic (As) were collected from An Giang Department of Natural Resources and Environment. These groundwater quality parameters were monitored twice a year, namely in March (the dry season) and in September (the wet season). The locations of the monitoring wells are shown in Figure 1.

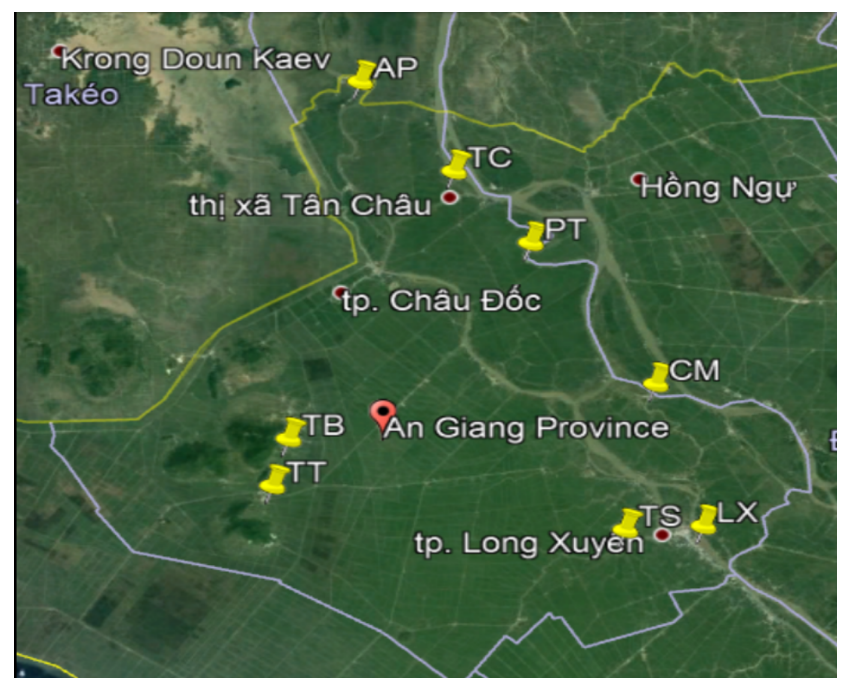

Figure 1. Locations of the groundwater monitoring wells

Note. AP: An Phu station; TC: Tan Chau station; PT: Phu Tan station; CM: Cho Moi station; LX: Long Xuyen station; TS: Thoai Son station; TB: Tinh Bien station; TT: Tri Ton station.

\subsection{Data analysis}

The variation in the groundwater quality parameters at the sampling sites was analyzed by one-way ANOVA using IBM SPSS statistics for Windows, Version 20.0 (IBM, 2011); Duncan test was applied to compare the difference in groundwater quality parameters at a significance level of $5 \%$ $(p<0.05)$. Groundwater quality parameters at monitoring wells were compared with the national technical regulation on groundwater quality (QCVN 09-MT: 2015/BTNMT) to assess groundwater quality.

\subsection{Health risk assessment}

Health risk was investigated in this study to assess the potential carcinogenic endpoint associated with the use of arsenic-contaminated groundwater. Health risk assessment was performed using the following steps:

\subsubsection{Hazard Identification}

Before starting any evaluation, structural alerts and physical-chemical parameters like water/lipid solubility and volatility need to be identified to screen for specific effects such as relative cytotoxicity, mutagenicity, or hormonal effects. This allows identification of specific wanted or unwanted effects of hazards. In this study, scientific and technical information relating to arsenic was collected, organized and evaluated to decide whether arsenic is likely to constitute a significant hazard to human health. The scientific data indicated that arsenic is carcinogen.

\subsubsection{Dose-Response Assessment}

Since arsenic is carcinogen, then the cancer slope factor (SF) value is used for the health risk assessment process. SF was referenced from the risk assessment website: 
https://cfpub.epa.gov/ncea/iris2/chemicalLanding.cfm?substance_nmbr=278 (US EPA, 2014).

\subsubsection{Exposure Assessment}

Exposure may be defined as the contact of a chemical, physical, or biological agent with the outer boundary of an organism. Exposure is usually defined as a function of time: An event that occurs when there is a contact boundary between a human and the environment with a contaminant of a specific concentration for an interval of time. In this study, arsenic is assumed via drinking pathway or ingestion. The chronic daily intake due to ingestion of groundwater could be calculated using Equation 1 (Thu, 2008):

$$
\mathrm{CDI}=\frac{\mathrm{C} \times \mathrm{IR} \times \mathrm{EF} \times \mathrm{ED}}{\mathrm{BW} \times \mathrm{AT}}
$$

where CDI is Chronic Daily Intake (mg/kg BW-day); C is the concentration of arsenic (mg/L); IR is Intake Rate (L/day); EF is Exposure Frequency (days/year); ED is Exposure Duration (70 years by convention); BW is Body Weight (kg); and AT is Averaging Time (days).

\section{Table 1. The relevant data for risk calculation}

\begin{tabular}{llllll} 
Receptors & IR (L/day) & EF (days/year) & ED (years) & BW (kg) & AT (days) \\
\hline Children & $1^{\mathrm{b}}$ & $365^{\mathrm{a}, \mathrm{b}, \mathrm{c}}$ & $70^{\mathrm{b}}$ & $10^{\mathrm{b}}$ & 25,550 \\
Adults & $3^{\mathrm{a}}$ & $365^{\mathrm{a}, \mathrm{b}, \mathrm{c}}$ & $70^{\mathrm{b}}$ & $55^{\mathrm{a}}$ & 25,550
\end{tabular}

${ }^{a}$ Mai et al., 2014; ${ }^{b}$ Thu, 2008; ${ }^{c}$ Quang, 2014

\section{Results and discussion}

\subsection{Groundwater quality in the period of 2009 - 2016}

The mean temperature in the groundwater in the period from 2009 - 2016 was $28.9 \pm 0.3^{\circ} \mathrm{C}$ (Figure 2a). The average temperatures and seasonal variation (dry and wet seasons) among monitoring wells were not significantly different ( $p>0.05$ ). The mean $\mathrm{pH}$ at the monitoring sites ranged from $6.6 \pm 0.1$ to $7.1 \pm 0.2$ which was in the neutral range (Figure 2b). The average total dissolved solids (TDS) has greatly fluctuated among monitoring wells (Figure $2 \mathrm{c}$ ). The value of TDS at Cho Moi station was the highest (4,516 \pm 2,768.7 mg/L) which was statistically significant difference with those in the other monitoring wells $(p<0.05)$. High levels of TDS in groundwater are mainly due to the presence of sulfate, iron and occasionally arsenic. The values of TDS in Tan Chau, Thoai Son, and Tri Ton stations were in accordance with the national technical regulation on groundwater quality (QCVN 09-MT: 2015/BTNMT) while TDS values in the other stations including An Phu, Phu Tan, Cho Moi, Long Xuyen and Tinh Bien were higher than the regulation. The variation of TDS between seasons at each groundwater well was not significantly different.

The mean hardness in groundwater at the monitoring wells ranged from $197 \pm 130.59 \mathrm{mg} / \mathrm{L}$ to 1,272 \pm 681.21
The most critical findings obtained from dose - response assessment and exposure assessment were combined. This step provides a description of the nature of the hazard and explicit accounting of the estimated degree of health risk. The cancer risk was calculated by using Equation 2:

where, SF is slope factor. According to the risk assessment website of U.S. Environmental Protection Agency, the slope factor of arsenic is 1.5 (mg/kg-day) $)^{-1}$ (US EPA, 2014). The acceptable health risk is one in million $\left(1 \times 10^{-6}\right)$ meaning that one person is likely to develop cancer due to drinking arsenic contaminated groundwater.

This study calculated cancer risk of arsenic due to groundwater consumption for two groups of receptors which were children and adults. The relevant information for estimating health risk was obtained from the previous studies (Quang, 2014; Mai et al., 2014; Thu, 2008) presented in Table 1.

\subsubsection{Risk Characterization}

$$
\text { Risk }=\text { CDI } \times \text { SF }
$$

mg/L (Figure 2d). Phu Tan station had the highest concentration of hardness at 1,272 $\pm 681.21 \mathrm{mg} / \mathrm{L}$, followed by Cho Moi station at 1,246 $\pm 297.73 \mathrm{mg} / \mathrm{L}$ and these values were significantly different from those found in the other monitoring stations $(p<0.05)$. The mean hardness of groundwater at An Phu, Phu Tan, Cho Moi, Long Xuyen were higher than the permitted hardness in groundwater according to QCVN 09-MT: 2015/BTNMT (500 mg/L). In the wells with high hardness concentration, groundwater quality is unsuitable for domestic use.

The mean level of nitrate $\left(\mathrm{NO}_{3}{ }^{-} \mathrm{N}\right)$ detected low in groundwater at all monitoring wells from 2009 to 2016, ranging from $0.09 \pm 0.13 \mathrm{mg} / \mathrm{L}$ to $0.99 \pm 0.98 \mathrm{mg} / \mathrm{L}$ (Figure 3a). The concentrations of nitrate were within the allowable limit. However, the nitrate concentrations were significantly different between wet season and dry season at Tinh Bien and Tri Ton stations. The average nitrate concentrations in groundwater at Tinh Bien and Tri Ton stations in dry season (March) and wet season (September) were $3.69 \pm 5.8$ $\mathrm{mg} / \mathrm{L}$ and $0.85 \pm 1.5 \mathrm{mg} / \mathrm{L}$ and $13.49 \pm 15.6 \mathrm{mg} / \mathrm{L}$ and 15.54 $\pm 27 \mathrm{mg} / \mathrm{L}$, respectively. It was highly possible that during the dry period, nitrate (from agricultural practices) has been accumulated and moved into the groundwater as surface water levels increased and stagnant. This could be a good example of the exchange of water and the transport of pollutants from surface water into the groundwater. 
Ammonium $\left(\mathrm{NH}_{4}{ }^{+}-\mathrm{N}\right)$ in groundwater fluctuated between $0.57 \pm 0.4$ and $5.06 \pm 2.7 \mathrm{mg} / \mathrm{L}$ and there were significant differences between the monitoring wells (Figure 3b). The highest $\mathrm{NH}_{4}{ }^{+}-\mathrm{N}$ concentration was found at Cho Moi station at $5.06 \pm 2.7 \mathrm{mg} / \mathrm{L}$ which was statistically significant different than the other stations. Ammonium concentration in Thoai Son station was the lowest and 8.88 times lower than the $\mathrm{NH}_{4}{ }^{+}-\mathrm{N}$ concentration found in Cho Moi station. At the all monitoring wells, the average $\mathrm{NH}_{4}{ }^{+}-\mathrm{N}$ concentration during dry season was $2.3 \pm 1.7 \mathrm{mg} / \mathrm{L}$ and $1.9 \pm 1.7$ $\mathrm{mg} / \mathrm{L}$ in the wet season. Among 8 monitoring wells, there were five wells in An Phu, Tan Chau, Phu Tan, Cho Moi and
Tri Ton where the concentration of $\mathrm{NH}_{4}{ }^{+}-\mathrm{N}$ was higher than the permitted standard regulated in QCVN 09MT:2015/BTNMT $\left(\mathrm{NH}_{4}{ }^{+}-\mathrm{N}<1 \mathrm{mg} / \mathrm{L}\right)$. The occurrence of $\mathrm{NH}_{4}{ }^{+}-\mathrm{N}$ in groundwater indicated the impact of human activities such as poultry, livestock, household waste, septic tanks, and aquaculture (Ly, 2008). In addition, the use of fertilizers for soil improvement and the supply of nutrients to crops also contributes to the increase in $\mathrm{NH}_{4}{ }^{+}-\mathrm{N}$ concentration in groundwater. This was consistent with the previous discussion that nitrate was also transferred from surface water to groundwater.
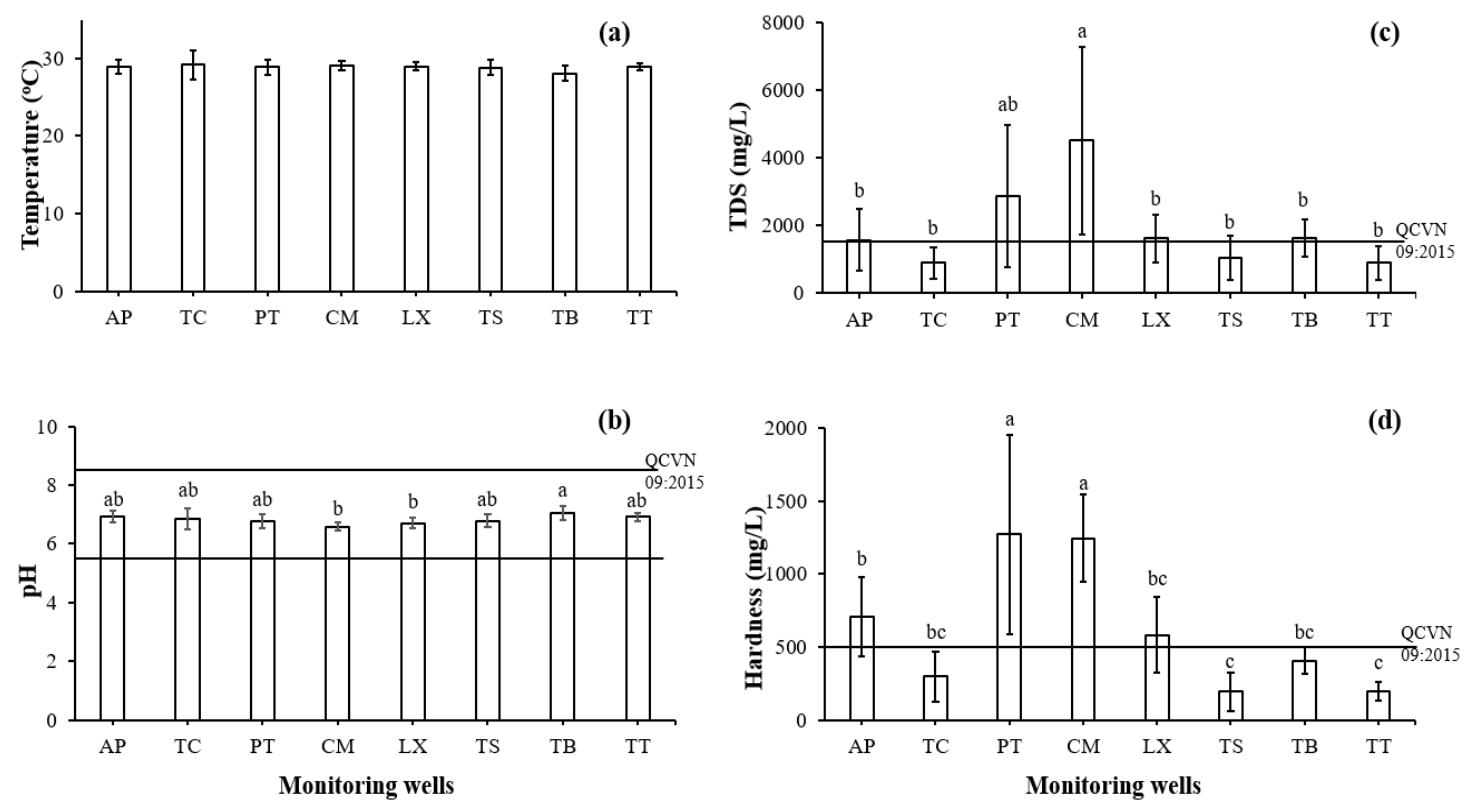

Figure 2. Variation of temperature (a), $\mathrm{pH}(\mathrm{b})$, TDS (c) and hardness (d) in groundwater at eight monitoring wells over the period of $2009-2016$

Note: Different letters in the same chart indicates statistically significant difference at a $=5 \%$.

QCVN 09:2015 National technical regulation on groundwater quality.
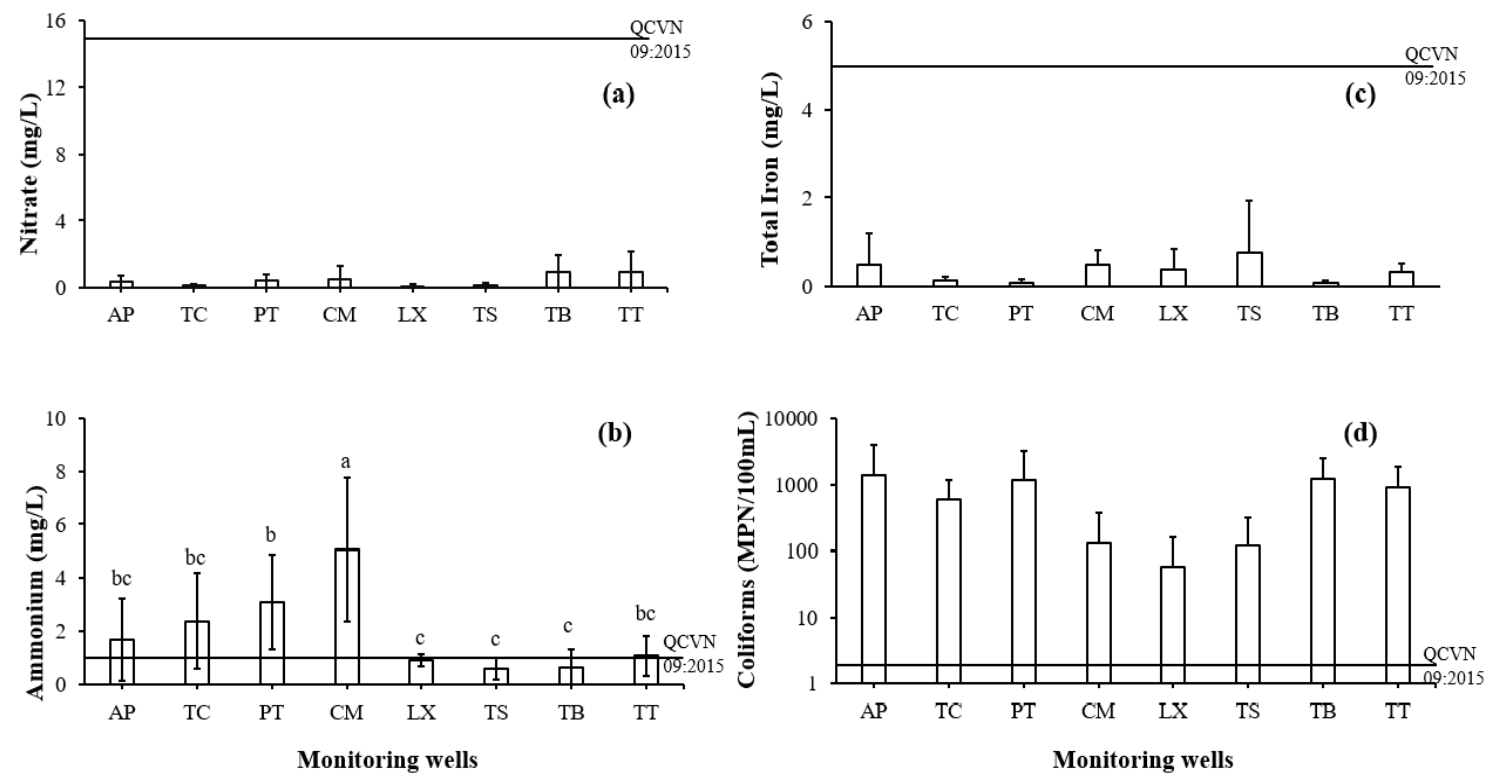

Figure 3. Variation of nitrate (a), ammonium (b), total iron (c) and coliforms (d) in groundwater at eight monitoring wells over the period of $2009-2016$

Note: Different letters in the same chart indicates statistically significant difference at $\alpha=5 \%$.

QCVN 09:2015 National technical regulation on groundwater quality 
The mean Fe concentration in groundwater was presented in Figure 3c. The highest concentration of total iron (2.16 \pm $3.36 \mathrm{mg} / \mathrm{L}$ ) was found at Thoai Son station and this concentration was statistically significant different than the remaining monitoring wells $(p<0.05)$. Total Fe found in groundwater at Phu Tan and Tinh Bien stations were relatively low at $0.07 \pm 0.07 \mathrm{mg} / \mathrm{L}$ and $0.07 \pm 0.05 \mathrm{mg} / \mathrm{L}$, respectively. There was no significant variation in Fe concentration in groundwater between the dry and wet seasons. Total iron concentrations at all monitoring wells were within the limit of the national technical regulation QCVN 09-MT: 2015/BTNMT (Fe<5 mg/L).

Coliforms in groundwater at all monitoring wells were relatively high (693.6 $\pm 543 \mathrm{MPN} / 100 \mathrm{~mL}$ ) (Figure 3d). The highest coliforms were recorded at An Phu and Tinh Bien stations at 1,374.6 \pm 2,632.5 MPN/100mL and 1,212.2 \pm 1,267.2 MPN/100mL, respectively. The density of coliforms in groundwater monitoring wells did not fluctuate significantly between dry and wet seasons. It is worth noting that coliforms in groundwater samples at all monitoring wells far exceeded the permitted level of QCVN 09-MT: 2015/BTNMT which permits only 3 MPN/100mL. Prior studies found that groundwater in the Mekong delta was heavily contaminated with coliforms (Sanh et al., 2010; Hoa, 2016). Microbial contamination in groundwater is one of the health risks for people who use both surface water and groundwater if the waters are not properly treated.

\subsection{Arsenic contamination and associated health risk due to groundwater consumption}

Arsenic concentrations have been detected in groundwater in An Giang province. The concentrations of arsenic in An Phu, Tan Chau and Long Xuyen stations were found at $0.3 \pm 0.63 \mathrm{mg} / \mathrm{L}, 0.54 \pm 1.18 \mathrm{mg} / \mathrm{L}$, and $0.55 \pm 1.21 \mathrm{mg} / \mathrm{L}$, respectively. The mean arsenic concentrations at all monitoring wells were presented in Table 2 . The average arsenic levels tended to increase in the wet season (September). This was in line with previous study reported that the concentration of arsenic in groundwater in the Mekong Delta increased considerably in wet season (Lap, 2005). Besides, this was similar to the increase in arsenic in the flood season of Red River plain (Berg et al., 2001).

The correlation between the levels of arsenic and total iron in the groundwater analyzed in An Giang province is unclear, but the two heavy metals were found closely related in the Red River delta and the Ganges River delta (Ky, 2009). For example, the highest arsenic concentration was in Long Xuyen station by $0.55 \pm 1.21 \mathrm{mg} / \mathrm{L}$, but the total iron concentration in this station was relatively low by $0.37 \pm$ $0.49 \mathrm{mg} / \mathrm{L}$. According to previous study, if the value of $\mathrm{pH}$ in natural environment is greater than 8.5 , arsenic will be easily released from the mineral surface such as pyrite, which increases the concentration of arsenic in groundwater (Duyen, 2017). However, in this study, the mean $\mathrm{pH}$ at the monitoring sites were in the neutral range from $6.6 \pm$ 0.1 to $7.1 \pm 0.2$ so this parameter has no significant effect on arsenic release.

\section{Table 2. Health risk associated with using groundwater contaminated by arsenic in An Giang province}

\begin{tabular}{|c|c|c|c|c|c|}
\hline \multirow[t]{2}{*}{ Station } & \multirow{2}{*}{$\begin{array}{l}\text { Concentration of } \\
\qquad \mathrm{As}^{1}(\mu \mathrm{g} / \mathrm{L})\end{array}$} & \multicolumn{2}{|c|}{ CDI (mg/kg.day) } & \multicolumn{2}{|c|}{ Cancer Risk } \\
\hline & & Children & Adults & Children & Adults \\
\hline $\mathrm{AP}$ & 300.77 & $3.01 \times 10^{-2}$ & $1.64 \times 10^{-2}$ & $4.51 \times 10^{-2}$ & $2.46 \times 10^{-2}$ \\
\hline TC & 538.35 & $5.38 \times 10^{-2}$ & $2.94 \times 10^{-2}$ & $8.08 \times 10^{-2}$ & $4.40 \times 10^{-2}$ \\
\hline PT & 13.84 & $1.38 \times 10^{-3}$ & $7.55 \times 10^{-4}$ & $2.08 \times 10^{-3}$ & $1.13 \times 10^{-3}$ \\
\hline CM & 5.23 & $5.23 \times 10^{-4}$ & $2.85 \times 10^{-4}$ & $7.85 \times 10^{-4}$ & $4.28 \times 10^{-4}$ \\
\hline$L X$ & 550.58 & $5.51 \times 10^{-2}$ & $3.00 \times 10^{-2}$ & $8.26 \times 10^{-2}$ & $4.50 \times 10^{-2}$ \\
\hline TS & 4.82 & $4.82 \times 10^{-4}$ & $2.63 \times 10^{-4}$ & $7.23 \times 10^{-4}$ & $3.94 \times 10^{-4}$ \\
\hline TB & 10.58 & $1.06 \times 10^{-3}$ & $5.77 \times 10^{-4}$ & $1.59 \times 10^{-3}$ & $8.66 \times 10^{-4}$ \\
\hline$\Pi$ & 4.71 & $4.71 \times 10^{-4}$ & $2.57 \times 10^{-4}$ & $7.07 \times 10^{-4}$ & $3.85 \times 10^{-4}$ \\
\hline QCVN 09-MT:2015/BTNMT & 50 & $5.00 \times 10^{-3}$ & $2.73 \times 10^{-3}$ & $7.50 \times 10^{-3}$ & $4.09 \times 10^{-3}$ \\
\hline $\mathrm{WHO}$ & 10 & $1.00 \times 10^{-3}$ & $5.45 \times 10^{-4}$ & $1.50 \times 10^{-3}$ & $8.18 \times 10^{-4}$ \\
\hline
\end{tabular}

Note: QCVN 09-MT:2015/BTNMT National technical regulation on groundwater quality.

'An Giang's Department of Natural Resources and Environment.

Arsenic concentrations at the monitoring wells in Phu Tan, Cho Moi, Thoai Son, Tinh Bien, and Tri Ton were within the allowable limit of QCVN 09-MT: 2015/BTNMT (As <0.05 $\mathrm{mg} / \mathrm{L}$ or $50 \mu \mathrm{g} / \mathrm{L})$. However, the concentration of arsenic in groundwater at An Phu, Tan Chau, and Long Xuyen were 6 times, 10.8 times, 11 times higher than the limit of the arsenic concentration regulated in QCVN 09-MT: 2015/BTNMT, respectively. The World Health Organization (WHO) recommends the arsenic level permitted for human consumption (drinking) should be equal or lower than 10 $\mu g / L$ (Yamamura et al., 2003). This recommended level by $\mathrm{WHO}$ is to reduce health risk associated with using groundwater as drinking water.

The calculated risks for children and adults were greater than acceptable risk level $\left(1 \times 10^{-6}\right)$ which could mean that the cancer risk due to presence of arsenic in groundwater in An Giang province ranged from medium to high. The highest cancer risk for both children and adults occurred in An Phu, Tan Chau and Long Xuyen stations (see Table 2). 
The medium cancer risk associated with groundwater consumption was found in Cho Moi, Thoai Son, and Tri Ton. This study found that children were likely to suffer higher cancer risk than adults, for example, the cancer risk estimation in Table 2 indicated that there are likely to have eight children and four adults (in 100 people) at risk of cancer in the Long Xuyen area. In Vietnam, the national technical regulation on groundwater quality (QCVN 09-MT: 2015/BTNMT) set the acceptable level of arsenic at $50 \mathrm{\mu g} / \mathrm{L}$. This level could lead to 75 children and 41 adults who are likely to have cancer risk in 10,000 people. The World Health Organization's standard limit is $10 \mu \mathrm{g} / \mathrm{L}$ which has contributed to dramatically decreasing the risk of cancer for both children and adults.

\section{Conclusions}

Based on the assessment of groundwater quality at eight monitoring wells in An Giang province for the period 2009 - 2016 and comparison with QCVN 09-MT: 2015/BTNMT, groundwater has been polluted with TDS, coliforms and arsenic. The levels of coliforms at all monitoring wells were high and exceeded the permitted level while concentrations of arsenic in groundwater at An Phu, Tan Chau and Long Xuyen stations were much higher than the permitted. The cancer risk calculation for both adults and children due to consumption of groundwater contaminated with arsenic indicated that both children and adults were at medium to high cancer risk. Treatment of arsenic in groundwater to bring the cancer risk to one in a million to minimize cancer risk to human health is urgently needed.

Acknowledgements. The authors gratefully acknowledge An Giang Department of Natural Resources and Environment for providing groundwater quality data from 2009 to 2016.

\section{References}

[1] An Giang People's Committee, 2015. Report on the state of environment in five years (2011 - 2015) of An Giang province. 181 pages (in Vietnamese).

[2] Appelo, T. (ed.), 2006. Arsenic in groundwater - a world problem. Proceedings of the Seminar organised by the Netherlands National Committee of the International Association of Hydrogeologists (NNC$\mathrm{IAH}$ ) in cooperation with the Netherlands Hydrological Society (HNV) in Utrecht, the Netherlands [retrieved on 06.10.2018 from http://bigfiles.nhv.nu/files/Arsenic_in_Groundwater_A_World_Problem.pdf].

[3] Berg, M., Tran, H.C., Nguyen, T.C., Pham, H.V., Schertenleib, R., Giger, W., 2001. Arsenic Contamination of Groundwater and Drinking Water in Vietnam: A Human Health Threat. Environmental Science and Technology, 35(13): 2621-2626.

[4] Duyen, V.T., 2017. Study on the distribution of arsenic content in groundwater and sediment in the northwestern of Hanoi. Master Thesis. Ha Noi National University (in Vietnamese).

[5] Ghassemi, F., Brennan, D., 2000. An evaluation of the sustainability of farming systems in the brackish water region of the Mekong Delta. Resource Profile Subproject: Summary Report. Australian Centre for International Agricultural Research, May 2000.

[6] Hoa, V.T., 2016. Evaluation of management activities and quality of rural water supply from groundwater in Tien Giang province. Bachelor thesis. Can Tho university (in Vietnamese).

[7] Hoang, T.H., Bang, S., Kim, K.-W., Nguyen, M.H. Dang, D.M., 2010. Arsenic in groundwater and sediment in the Mekong River delta, Vietnam. Environmental Pollution. 158(8): 2648 - 2658.

[8] IBM, 2011. IBM SPSS statistics for Windows, Version 20.0. Armonk, NY, USA.

[9] Ky, N.V, 2009. Situation of arsenic pollution in the Mekong Delta. Journal of Science and Technology Development. 101-112. (In Vietnamese)

[10] Lap, N.V., 2005. Status of arsenic pollution in ground water of Tan Hong district, Dong Thap province. Provincial research project (in Vietnamese).

[11] Ly, N.K., 2008. Environmental pollution in animal husbandry activities and solutions (in Vietnamese).

[12] Mai, N.T.P, Hue, N.T. and Thao, N.T.P., 2014. Assessment of arsenic accumulation level in hair and nails of residents living in region of multi - metal ore exploitation in Nui Phao, Thai Nguyen. Journal of Chemical, Physical and Biological Analysis. 19: 21-26 (in Vietnamese).

[13] QCVN 09-MT: 2015/BTNMT National technical regulation on groundwater quality (in Vietnamese).

[14] Quang, N.H., 2014. Health risk assessment for arsenic pollution in groundwater in Ho Chi Minh City. VNU Journal of Science: Earth and Environmental Sciences. 30: 50-57 (in Vietnamese).

[15] Sanh, N.V., Son, N.N., Tuan, V.V. and Khoi, L.D., 2010. Research on water resources in Tra Vinh: Current status of exploitation, use and solutions for sustainable use management. Journal of Science, 15b: 167-177 (in Vietnamese).

[16] Thu, N.T., 2008. Arsenic pollution in groundwater and health risk assessment for people in Don Duong and Duc Trong district, Lam Dong province. Bachelor thesis. Da Lat University (in Vietnamese).

[17] US EPA, 2014. United States Environmental Protection Agency. Arsenic, inorganic. CASRN 7440-38-2 [retrieved on 06.10.2018 from https://cfpub.epa.gov/ ncea/iris2/chemicalLanding.cfm?substance_nmbr=278]. 
[18] Vietnam's Department of Water Resources Management, 2009. Groundwater in the Mekong Delta is 1215 meters lower. [retrieved on 04.10.2018 from http://dwrm.gov.vn/index.php?lan-

guage=vi\&nv=news\&op=Tai-nguyen-nuoc/Nuocngam-tai-Dong-bang-song-Cuu-Long-tut-giam-1215-met-521]
[19] Yamamura, S., Bartram, J., Csanady, M., Gorchev, H. G., and Redekopp, A., 2003. Drinking Water Guidelines and Standards. Arsenic, water, and health: the state of the art [retrieved on 06.10.2018 from http://www.who.int/water_sanitation_health/dwq/arsenicun5.pdf]. 